\title{
Професійний стандарт фітнес-консультанта: затребуваність, модель формування, обґрунтування проєкту
}

\author{
Мирослав Дутчак, Дар’я Усенко, Уляна Катерина
}

Національний університет фізичного виховання і спорту України, Київ, Україна

Анотація. Статтю присвячено вирішенню актуального наукового питання щодо стандартизації професійної діяльності фітнес-консультанта з урахуванням особливостей розвитку вітчизняної системи оздоровчого фітнесу та передового міжнародного досвіду. Мета. Наукове обгрунтування моделі формування професійного стандарту фітнес-консультанта для визначення сучасних вимог до трудових функцій, загальних та професійних компетентностей відповідних фахівців в Україні. Методи. Теоретичний аналіз наукової літератури, структурно-функціональний аналіз, соціологічні методи (анкетне опитування, експертне оцінювання, соціальне моделювання), педагогічні методи (спостереження, тестування), методи математичної статистики. Результати. В ході дослідження визначено спільні ознаки різних науково-практичних підходів та охарактеризовано сучасні світові тенденції, що необхідно враховувати під час розробки проєкту професійного стандарту. На основі наведених вище наукових положень розроблено модель формування професійного стандарту фітнес-консультанта, що об'єднує три блоки: підготовчий, проєктний та контрольно-коригуючий. Відповідно до обґрунтованої моделі розроблено проєкт стандарту фітнес-консультанта з урахуванням частоти застосування та важливості кожної трудової дії, розподілу трудових дій за трудовими функціями, визначення переліку знань, умінь та навичок, динамічна комбінація яких визначає здатність особи до реалізації певної трудової функції. Валідність розробленого проєкту професійного стандарту підтверджено результатами експертного оцінювання. Визначено механізм та суб'єкти впровадження професійного стандарту фітнес-консультанта. Ключові слова: система оздоровчого фітнесу, фітнес-консультант, професійний стандарт, трудові фрункції, трудові дії, компетентності.

Myroslav Dutchak, Daria Usenko, Uliana Kateryna

\section{PROFESSIONAL STANDARD OF A FITNESS CONSULTANT: DEMAND FOR, MODEL OF FORMATION, JUSTIFICATION OF THE DRAFT}

Abstract. The article addresses a relevant scientific issue of standardization of professional activity of a fitness consultant taking into account the peculiarities of development of the national system of health fitness and international best practices. Objective. To provide scientific substantiation for the model of formation of professional standard of a fitness consultant to identify modern requirements to labor functions and general and professional competencies of these professionals in Ukraine. Methods. Theoretical analysis of scientific literature, structural and functional analysis, sociological methods (questionnaire survey, expert evaluation, social modeling), pedagogical methods (observation, testing), methods of mathematical statistics. Results. In the course of the study, the common features of different scientific and practical approaches were identified and modern world tendencies were characterized, which should be taken into account when developing the draft of professional standard. Based on the above-mentioned scientific provisions, a model of formation of a professional standard of a fitness consultant was developed which consists of three blocks: preparatory, drafting, and control and corecting ones. According to the substantiated model, a draft of the standard of a fitness consultant was developed taking into account the frequency and importance of every work action, distribution of work actions by job functions, and defined list of knowledge, skills and abilities, dynamic combination of which determines a person's ability to perform a job. The validity of the developed draft of professional standard was confirmed by the results of expert evaluation. The mechanism and subjects of implementation of the professional standard of a fitness consultant were defined.

Keywords: the system of health-enhancing fitness, fitness-consultant, professional standard, job functions, work actions, competencies.

Dutchak M., Usenko D., Kateryna U.

Professional standard of a fitness consultant: demand for, model of formation, justification of the draft. Theory and Methods of Physical education and sports. 2021; 3: $67-73$

DOI: 10.32652/tmfvs.2021.3.67-73
Дутчак М., Усенко Д., Катери-

на У. Просресійний стандарт фрітнесконсультанта: затребуваність, модель формування, обґрунтування проєкту. Теорія і методика фрізичного виховання і спорту. 2021; 3: 67-73

DOI: 10.32652/tmfvs.2021.3.67-73
Вступ. Система оздоровчого фрітнесу в Україні активно розвивається $[1,13]$. В умовах підвищення запитів населення до якості фрітнес-послуг з урахуванням нових викликів, появи інноваційних фітнес-технологій, зростання секторальної ринкової конкуренції актуалізується проблема належного кадрового забезпечення відповідної сфери. Сьогодні існує значна кількість наукових підходів та методичних напрацювань, які стосуються формування професійної майстерності фахівців з оздоровчого фрітнесу [2, 3, 8, 12, 14]. Проте більшість із них спрямовані на удосконалення та оптимізацію процесу професійної підготовки фрахівців, змісту освіти, професійного навчання, рівня компетентності. Але недостатньо вивченими залишаються питання змісту професійної діяльності фахівців з оздоровчого фітнесу, в тому числі і для професії фрітнес-консультанта [11, 19]. Враховуючи сказане, можна говорити про те, що існує потреба у розробці професійного стандарту для фітнесконсультанта, який міститиме характеристику їхніх трудових функцій та дій, компетентностей, знань, умінь та навичок, необхідних для успішної профресіоналізації.

Мета дослідження - науково обґрунтувати модель формування професійного стандарту фітнес-консультанта для визначення сучасних вимог до трудових фрункцій, загальних та професійних компетентностей відповідних фрахівців в Україні.

Методи дослідження: аналіз наукової літератури, ресурсів мережі Інтернет; опитування; соціальне моделювання; педагогічне спостереження; методи математичної статистики.

Результати дослідження та їх обговорення. Нами здійснювався теоретичний аналіз наукової літератури, інформаційних ресурсів мережі Інтернет та документальних джерел, передового зарубіжного та вітчизняного 
досвіду для характеристики професійної діяльності фрітнес-консультанта. Структурно-фрункціональний аналіз використовували для забезпечення системного підходу до формування професійного стандарту фрітнесконсультанта. Анкетне опитування було спрямоване на вивчення ступеня затребуваності профресії фрітнесконсультанта в умовах фрункціонування фрітнес-клубів. Під час експертного оцінювання проведено аналіз трудових функцій та дій фрітнесконсультантів за такими критеріями: ступінь їх значущості та частота використання. Соціальне моделювання ми використовували для обґрунтування моделі формування професійного стандарту фітнес-консультанта. Педагогічні спостереження проводили за реалізацією професійної діяльності фотнес-консультанта, зокрема надання послуг на базі фрітнес-клубу та поза його межами. Педагогічне тестування було проведене для визначення рівня теоретичної підготовленості фахівців з оздоровчого фітнесу до здійснення професійної діяльності фітнес-консультанта. Для кількісного аналізу фактичного матеріалу дослідження використано методи математичної статистики.

у ході дослідження встановлено, що в Україні спостерігається відсутність системних наукових знань та обґрунтованості трудової діяльності фрахівців зі збереження та зміцнення здоров'я $[4,9,10]$, що привело до аналізу проблеми дослідження у міжнародному контексті.

Пріоритетною для профресії фрітнес-консультанта у США визнається діяльність, пов'язана 3 формуванням мотивації на зміну моделей поведінки клієнта, що веде до розкриття внутрішнього потенціалу особистості в напрямі зміцнення здоров'я [16, 17]. Для європейського профресійного ринку ключовими виступають функції, пов'язані безпосередньо з плануванням та організацією рухової активності клієнтів для ведення здорового способу життя $[15,18]$.

Різні підходи використовуються також для визначення назви професії таких фрахівців, найбільш характерними з яких є Health Coach; Wellness
Coach - для США та Exercise for Health Specialist; Health and Fitness Advanced Specialist - для європейських країн. Проведений порівняльний аналіз професійних стандартів зарубіжних країн $[15,16,18]$ дав можливість сфрормувати перелік основних положень вітчизняного стандарту фітнес-консультанта: трудових функцій, дій, компетентностей, знань умінь та навичок, які потім доцільно піддати експертному оцінюванню на відповідність сучасним особливостям розвитку системи оздоровчого фрітнесу в Україні.

Встановлено, що в Україні доцільно використовувати поняття «фітнесконсультант» для означення узагальненої назви професії фрахівців, діяльність яких спрямована на формування, збереження та зміцнення здоров'я особи шляхом використання оздоровчо-рекреаційної рухової активності в органічному поєднанні 3 іншими компонентами здорового способу життя $[10,11,19]$. Просресія фітнес-консультанта має високий рівень затребуваності споживачами фітнес-послуг та роботодавцями системи оздоровчого фітнесу.

Дослідження мотивації свідчить, що група оздоровчих мотивів є значущою для населення різних вікових груп. У ході проведеного анкетування визначено, що пріоритетними мотивами для більшості споживачів фрітнеспослуг (73 \% респондентів) стали мотиви, пов'язані 3 корекцією статури. Ключовими у цьому відношенні $є$ бажання зменшити масу тіла, удосконалити його загальну форму та/або окремих частин, збільшити м'язовий компонент, скорегувати поставу. Група оздоровчих цілей, до якої відносять забезпечення належного рівня здоров'я, профрілактику захворювань, підвищення фрізичної підготовленості, є також досить значущою для більшості респондентів (68 \%). Отримані результати свідчать про те, що люди все частіше усвідомлюють цінність свого здоров'я та необхідність здійснення діяльності у напрямі його збереження і покращення.

Цікавим $є$ факт, що мотиви, які характеризують якість життя людини, у тому числі й ефрективність професійної діяльності, на сьогодні також за- ймають одну із пріоритетних позицій. До цієї групи входять мотиви покращення роботоздатності, зменшення стомлюваності, підвищення продуктивності трудової діяльності, якій віддали перевагу 56 \% респондентів.

Далі ми вивчали питання, що стосується того, яка кількість респондентів мали досвід співпраці 3 фахівцями зі збереження та зміцнення здоров'я та як вони можуть оцінити якість надання послуг такими фахівцями. На запитання «Чи користувалися Ви послугами фітнес-консультанта (health coach, wellness coach, консультанта зі здорового способу життя)?» $43 \%$ респондентів відповіли ствердно, 23 \% - співпрацювали із вказаними фрахівцями дистанційно за допомогою мережі Internet, 16 \% мали досвід співпраці у межах корпоративних програм оздоровлення за місцем роботи та лише 4 \% респондентів користувалися послугами фітнес-консультанта у фітнес-клубі.

Також встановлено, що співпраця з фітнес-консультантом для більшої частини споживачів відбувалася під час короткострокових онлайнпрограм, фрітнес-марафонів, програм схуднення тощо. 3 числа опитаних лише $8 \%$ зазначили, що їхній спосіб життя після проходження програми змінився, решта вказали, що після закінчення програми вони з часом повернулися до звичного способу життя. Лише 12 \% респондентів зазначають, що проходили такі програми повторно, а для більшості опитаних це був одноразовий досвід.

Дослідження затребуваності профресії фрітнес-консультанта у роботодавців системи оздоровчого фітнесу дозволяє стверджувати, що абсолютна їх більшість (77 \% респондентів) вважає за доцільне впровадження професії фрітнес-консультанта, тоді як лише 9,3 \% з них констатують, що мають таку посаду у штатних розписах фрітнес-клубів преміум сегмента.

На запитання «Чи є у штатному розписі Вашої організації посада фрітнес-консультанта» лише 9,3 \% відповіли позитивно, серед яких 4,1\% вказали саме на посаду «фрітнесконсультант», 3,4 \% - «консультант зі здорового способу життя», 1,8 \% - 
«лікар первинної функціональної діагностики». Також 4,2 \% опитуваних зазначили, що така посада у них була раніше, а нині відсутня.

Серед чинників, що стримують впровадження профресії фрітнес-консультанта в умовах вітчизняної системи оздоровчого фітнесу, 52 \% роботодавців зазначають нестачу кваліфрікованих кадрів, які можуть обіймати цю посаду, 29 \% - обрали варіант відповіді про відсутність розуміння змісту їхньої професійної діяльності, 14 \% - відмітили низький інтерес споживачів фрітнес-послуг до професійної діяльності фотнес-консультанта через відсутність інформації про їі зміст, 5 \% вказали на низький рівень розвитку вітчизняної системи оздоровчого фрітнесу.

Отримані результати дозволяють зробити висновок, що профресія фрітнес-консультанта на ринку праці досить затребувана, однак лімітуючими чинниками на шляху її впровадження в практичну діяльність фрітнес-клубів $€$ відсутність єдиного науково обґрунтованого підходу до визначення основного кола трудових функцій та професійних компетентностей, що ускладнює визначення їхніх функціональних обов'язків, розробку посадових інструкцій та критеріїв відбору на посаду.

Лімітуючим чинником виступає також відсутність фрахівців, які володіють системними знаннями та можуть здійснювати таку діяльність, що й обумовило дослідження готовності фітнес-персоналу до виконання трудових фрункцій фрітнес-консультанта. Для оцінювання рівня знань тренерів з професійної діяльності фрітнесконсультанта нами було використано систему тестування Національного комітету 3 підвищення кваліфікації Health \& Wellness Coaching (NBC-HWC), що функціонує під егідою Міжнародної ради 3 Health and Wellness Coaching (NBHWC, CША) [16]. Вказана організація є визнаним світовим лідером серед провайдерів навчання та сертифікації фахівців зі збереження та зміцнення здоров'я. Система тестування включала 30 теоретичних та 15 ситуаційних запитань, розподіле-

Т а б л и ц я 1. Структура тестування та результати оцінювання рівня готовності фітнес-персоналу до виконання трудових функцій фрітнес-консультанта, $\mathrm{n}=40$

\begin{tabular}{|l|c|c|}
\hline \multicolumn{1}{|c|}{ Тематичний розділ } & $\begin{array}{c}\text { Кількість та частка } \\
\text { запитань, \% }\end{array}$ & $\begin{array}{c}\text { Частка правильних } \\
\text { відповідей, \% }\end{array}$ \\
\hline Побудова та організація тренувального процесу & $20(n=9)$ & 71 \\
\hline $\begin{array}{l}\text { Процес коучингу (ефективна комунікація, } \\
\text { мотивація до дії, контроль результативності) }\end{array}$ & $49(n=22)$ & 65 \\
\hline Здоров'я та оздоровчий спосіб життя & $20(n=9)$ & 83 \\
\hline Етичні та юридичні аспекти діяльності & $11(n=5)$ & 42 \\
\hline
\end{tabular}

них на блоки залежно від тематичного спрямування.

У ході дослідження виявлено, що рівень знань фрітнес-персоналу, необхідного для виконання трудових функцій фотнес-консультанта, $€$ достатнім для здійснення відповідної професійної діяльності. Найвищим $є$ рівень обізнаності тренерів про концепцію здоров'я та здорового способу життя (83 \% правильних відповідей на запитання цього блоку) (табл. 1).

Найнижчим $€$ рівень обізнаності фахівців з оздоровчого фітнесу про етичні та юридичні аспекти діяльності фрітнес-консультанта - 42 \% правильних відповідей, а також про суть та організаційні аспекти процесу коучингу - $65 \%$.

Наступним етапом дослідження стало визначення науково-практичних підходів до фрормування професійного стандарту фітнес-консультанта, до яких відносять: першочергове визначення трудових функцій, дій та трудових операцій як ключової складової професійного стандарту, і лише потім - професійних компетентностей, що забезпечують успішне виконання визначених функцій; оцінювання трудових функцій та дій за двома критеріями: важливістю та частотою використання; залучення широкого кола практиків до оцінювання трудових дій та операцій; проведення процедури публічного обговорення проєкту стандартів [10].

Сучасні світові тенденції з розробки професійного стандарту фрітнесконсультанта передбачають: форомування системи тісної взаємодії між ринком праці та освітньою діяльністю, що ґрунтується на результатах навчання; зростання кількості використовуваних методів та інформаційних ресурсів; широке та інтенсивне залучення стейкхолдерів до розробки професійних стандартів (переважна більшість країн запроваджує обов'язкову участь зацікавлених сторін для збільшення відповідності й легітимності стандартів до умов ринку праці); впровадження проєктів 3 напрацювання спільних (європейських, міжнародних) розробок та компетентностей професій, які будуть використовуватися як основа для впровадження національних стандартів і навчальних програм, що сприятиме гнучкості міжнародної мобільності фахівців; застосування прозорої та ефективної процедури уніфрікації та стандартизації професійної діяльності, формування єдиних вимог до рівня професіоналізму та компетентностей персоналу на міжнародному рівні $[12,19]$.

На основі аналізу результатів проведених нами досліджень затребуваності профресії фрітнес-консультанта у вітчизняній системі оздоровчого фітнесу, вивчення науково-практичних підходів і сучасних тенденції формування професійного стандарту фітнесконсультанта у міжнародному і вітчизняному дискурсі та 3 урахуванням розглянутих тематичних нормативноправових документів і ключових положень методу моделювання соціальних процесів нами розроблено модель формування просресійного стандарту фітнес-консультанта, що об'єднує три блоки: підготовчий, проєктний та контрольно-коригуючий. Визначено перелік відповідних операцій у кожному з цих блоків (рис. 1).

Підготовчий блок включає виконання таких процедур: надання характеристики сучасним тенденціям розвитку професійної діяльності фітнес-консультанта; узагальнення між- 


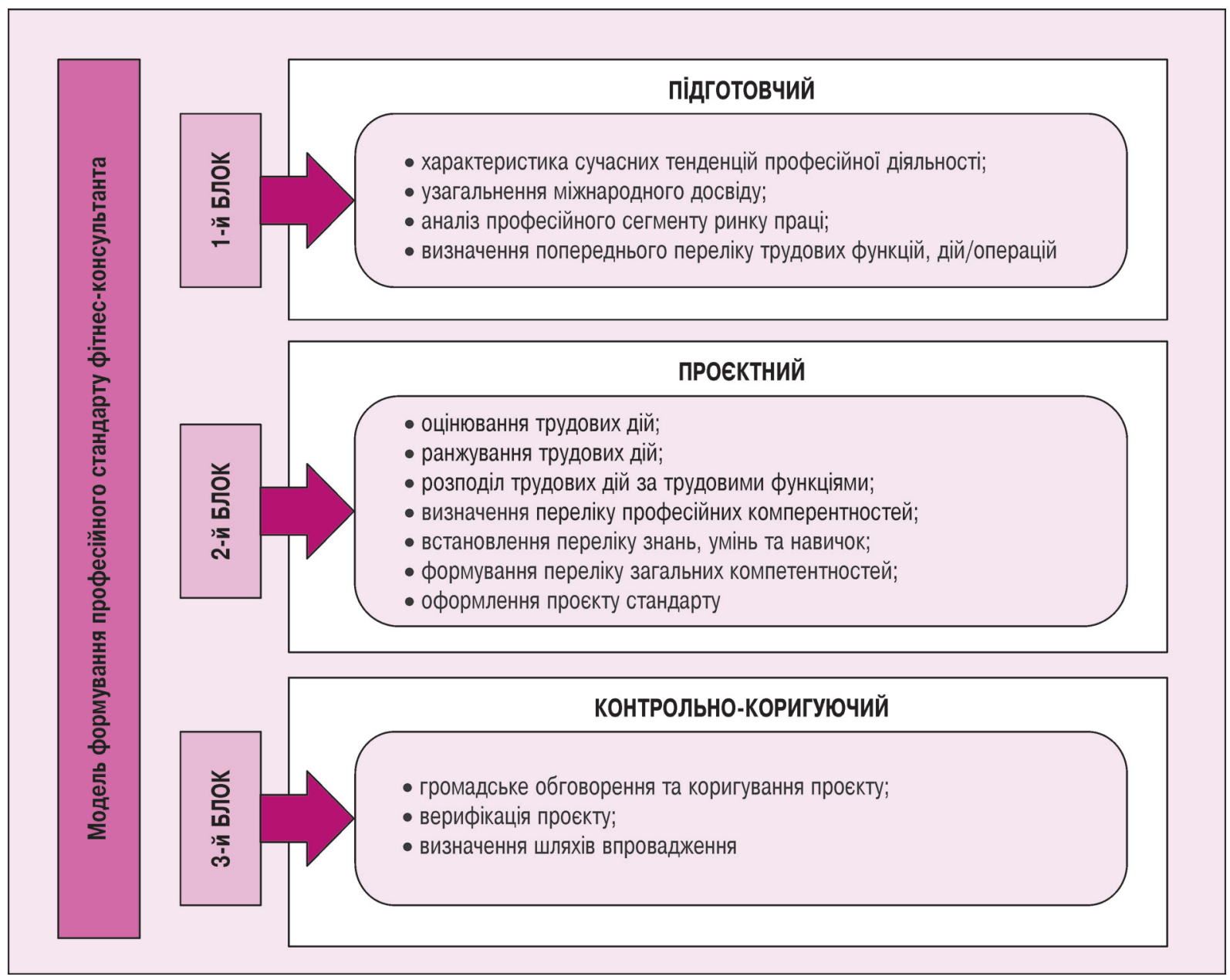

Рисунок 1 - Модель фрормування профресійного стандарту фрітнес-консультанта

народного досвіду стандартизації професійної діяльності фітнес-консультанта; проведення аналізу професійного сегменту ринку праці фрітнесконсультанта; визначення попереднього переліку трудових фрункцій фрітнес-консультанта, трудових дій/операцій, що забезпечують реалізацію цих фрункцій (за даними літературних та інформаційних джерел).

Проєктний блок спрямовується на: оцінювання частоти застосування та важливості кожної трудової дії фотнес-консультанта з їх попереднього переліку; здійснення ранжування (за ступенем значущості) трудових дій фотнес-консультанта; розподіл трудових дій за трудовими фрункціями фрітнес-консультанта, формування кінцевого переліку таких функцій; визначення професійних компетентностей фрітнес-консультанта, необхідних для реалізації їхніх трудових функцій; встановлення переліку знань, умінь та навичок, динамічна комбінація яких визначає професійні компетентності фрітнес-консультанта; формування перелікузагальних компетентностей фітнес-консультанта; оформлення проєкту просресійного стандарту фрітнесконсультанта.

Контрольно-коригуючий блок передбачає виконання таких операцій: громадське обговорення та коригування проєкту професійного стандарту ффітнес-консультанта; верифрікація проєкту просресійного стандарту фрітнес-консультанта; визначення шляхів впровадження стандарту фрітнес-консультанта.

Розроблений проєкт професійного стандарту фрітнес-консультанта містить визначені структурні елементи та складається 3 шести розділів.

Загальні відомості стандарту включали мету, назву виду економічної та професійної діяльності, професійну назву роботи, назви типових по- сад, місце профресії в організаційній структурі підприємства, умови допуску до роботи, документи, що підтверджують професійну та освітню кваліфрікації.

Перелік загальних компетентностей містив 10 положень, серед яких здатність до саморозвитку та навчання, здатність мотивувати людей, оцінювати та забезпечувати якість виконаних робіт тощо. Перелік трудових дій включав 66 дій, які були розподілені відповідно до дев'яти трудових фрункцій, представлених за значущістю. Опис просесійних компетентностей, необхідних для виконання трудових функцій, об'єднував 25 компетентностей, серед яких такі здатності: розробляти програму оздоровлення клієнтів з урахуванням результатів первинної діагностики, що передбачає підбір засобів та параметрів навантаження, рекомендації $з$ раціонального харчування, профілактики виникнен- 
ня захворювань та стресів, активного дозвілля, засобів відновлення після навантаження; до здійснення контролю за ефективністю програм оздоровлення; добирати методи діагностики 3 урахування індивідуальних особливостей клієнтів тощо. Перелік професійних компетентностей визначався за кожною трудовою функцією окремо, а також містив опис знань умінь та навичок, необхідних для ефективної діяльності у цій предметній ссрері. Технічні дані стандарту включали інформацію про розробників та суб'єктів перевірки проєкту стандарту.

Валідність розробленого проєкту професійного стандарту фрітнесконсультанта підтверджено результатами експертного оцінювання за 10 критеріями. Найвищу оцінку (8,96 бала 310 можливих) 3 незначною варіацією $(5,01 \%)$ отримав показник «Пов'язаність об'єкта із зовнішнім середовищем (відповідності сучасним вимогам професійного сегменту ринку)». Також досить високо експерти оцінили «Коректність віднесення стандарту до визначеного розділу, підрозділу, класу, підкласу та групи професій» (8,91 бала, коефріцієнт варіації - 3,56 \%), «Репрезентативність вибірки експертної групи, залученої до формування проєкту стандарту» (8,75 бала, коесріцієнт варіації - 4,36 \%), «Придатність профресійного стандарту для розробки освітніх стандартів, навчальних планів і програм» (8,4 бала, коесріцієнт варіації - 7,05 \%) та «Можливість здійснення на основі стандарту сертифікації набутих компетентностей фахівців» $(7,41$ бала, коефріцієнт варіації - 9,94\%).

Суб'єктами впровадження професійного стандарту фрітнес-консультанта є: срахівці цієї професії; роботодавці системи оздоровчого фітнесу; заклади освіти (фрормальної та неформальної); органи державної влади. Впровадження професійного стандарту роботодавцями системи оздоровчого фітнесу (їх об'єднаннями) передбачає реалізацію таких шляхів: аналіз, дослідження та використання основних положень стандарту, змін та доповнень до нього; аналіз штатного розпису організацій на предмет відпо- відності назв посад фахівців вимогам професійного стандарту; актуалізація посадових інструкцій та інших локальних актів і документів (функціональні обов'язки, правила внутрішнього розпорядку, положення тощо); визначення відповідності компетентностей фрахівців вимогам стандарту; розробка та реалізація плану заходів із додаткового професійного навчання та підвищення кваліфікації фрахівців відповідно до вимог стандарту.

Дискусія. Професія фрітнес-консультанта є однією 3 нових у вітчизняній системі оздоровчого фрітнесу. у зв'язку з цим ми можемо констатувати фрактичну відсутність у вітчизняній літературі наукових досліджень, які б стосувалися визначення назви професійної діяльності таких фахівців, змісту, трудових функцій та компетентностей. У ході аналізу численних літературних джерел $[16,17]$ виявлено, що у сфрері збереження та зміцнення здоров'я зарубіжних країн (США, Канади, Австралії), найбільш широко використовуються такі назви відповідної просресії: «Health coach» та «Wellness coach», рідше «Health Promotion Specialist», «Specialist in exercises for health». В європейському секторі назви професії фрахівців, діяльність яких пов'язана зі збереженням та зміцненням здоров'я населення, визначаються як «Exercise for health specialist», «Health and fitness advanced specialist» та суміжні назви професій «Pre-Diabetes Exercise Specialist», «Weight Management Exercise Specialist» $[14,15,18]$.

Аналіз переліку посад вітчизняного фрітнес-персоналу, опитування фрахівців $[9,11,19]$ показали, що в Україні подібна диференціація професій тільки формується, тому ряду назв трудової діяльності, популярних у зарубіжній практиці, не має у нормативно визначених профресіях сфрери фрізичної культури і спорту і вони не представлені в Національному класифікаторі України «Класифікатор професій ДК 003: 2010» [7]. Відповідно до зазначеного документа профресія фрахівців зі збереження та зміцнення здоров'я визначається як «консультант 3 питань здорового способу життя» та відповідає коду КП 2351.2, який належить до розділу 2 «Професіонали» підрозділу 235 «нші професіонали в галузі навчання» підкласу 2351.2 «ннші професіонали в галузі методів навчання». Цей клас за своєю суттює вищим аніж клас, до якого належить професія «фітнес-тренер», що передбачає підвищені вимоги до рівня їх компетентностей, та вимагає освітнього ступеня магістра й належить до розділу «Профресіонали» [7]. Також варто зазначити, що у Довіднику кваліфікаційних характеристик професій працівників кваліфікаційна характеристика для консультанта 3 питань здорового способу життя відсутня. Зазначене ускладнює розуміння змісту їхньої професійної діяльності, в тому числі професійних функцій, завдань, обов'язків та повноважень.

Отримані результати, узгоджуються з численними дослідженнями науковців [3, 8, 14] та свідчать про необхідність внесення змін до Національного класифікатора професій, оскільки зазначений документ містить цілий ряд архаїчних положень, що не відповідають вимогам сьогодення та сучасним європейським підходам. Більшість назв професій у сорері оздоровчого фрітнесу практично не використовують на ринку праці фрітнес-персоналу [12]. Невідповідність назв та змісту професій фрахівців з оздоровчого фрітнесу сучасним умовам суттєво обмежує розробку відповідних нормативних документів, що регламентують їх професійну діяльність та підготовку до неї, зокрема професійних та освітніх стандартів, навчальних програм, кваліфікаційних характеристик тощо.

Зазначене свідчить про необхідність здійснення діяльності, спрямованої на оновлення та розширення переліку посад фахівців з оздоровчого фрітнесу у вказаному вище національному класифрікаторі [7]. Для цього доцільним ми вважаємо використання європейського досвіду зі створення системи секторальних кваліфікацій (SQF), яка б узгоджувалася з європейською та національною рамками кваліфікацій. Таким чином, простежуватиметься ієрархічність професій, що визначається освітнім рівнем фрахівців і стимулює їх постійно приділя- 
ти увагу підвищенню своєї кваліфрікації [15].

Подібна ситуація стосується і назви професії «консультант зі здорового способу життя». В ході проведеного нами дослідження встановлено, що серед роботодавців більш поширеним $€$ досвід використання назви профресії фрітнес-консультант або ж англомовних варіантів health та wellness coach. Враховуючи зарубіжний досвід [15-18], результати вітчизняних наукових досліджень [4, 10 $11,19]$, національні особливості розвитку системи оздоровчого фрітнесу в Україні $[5,12]$ та існуюче законодавство [6], ми прийшли до висновку про доцільність використання терміна «фрітнес-консультант» для визначення узагальненої назви професії фрахівців, діяльність яких спрямована на формування, збереження та зміцнення здоров'я особи шляхом використання оздоровчо-рекреаційної рухової активності в органічному поєднанні 3 іншими компонентами здорового способу життя.

Висновки. В ході дослідження встановлено високу затребуваність профресії фрітнес-консультанта в Україні споживачами фрітнес-послуг та роботодавцями системи оздоровчого фрітнесу, достатній рівень готовності фітнес-персоналу до виконання трудових функцій фрітнес-консультанта Розроблена модель фрормування професійного стандарту фітнес-консультанта в Україні ґрунтується на сучасних науково-практичних підходах, вітчизняних нормативно-правових актах і передовому міжнародному досвіді та включає підготовчий, проєктний, контрольно-корегуючий блоки, що передбачають вивчення фрактичного стану та перспектив трудової діяльності, фрормування проєкту професійного стандарту, його громадське обговорення та верифрікація, визначення шляхів впровадження у практику. Проєкт професійного стандарту фітнес-консультанта містить визначені структурні елементи та характеристику його трудових ффункцій, дій, загальних та спеціальних компетентностей, необхідних для здійснення професійної діяльності 3 урахуванням вітчизняних особливостей розвитку системи оздоровчого фрітнесу.

Перспективи подальших досліджень передбачають вивчення особливостей безперервного професійного розвитку фітнес-консультантів та запровадження системи їх сертифікації.

Конфлікт інтересів. Автори заявляють, що відсутній будь-який конфрлікт інтересів.

\section{ЛITEPATУРA}

1. Андрєєва 0, Дутчак М, Благій 0. Тео ретичні засади оздоровчо-рекреаційної рухово активності різних груп населення. Теорія і методика фріз. виховання і спорту. 2020;2:59-66 doi: 10.32652/tmfvs.2020.2

2. Василенко ММ. Теоретичні і методичн засади професійної підготовки майбутніх фріт нес-тренерів у закладах вищої освіти [автореферат]. Київ; 2018. 44 с.

3. Дутчак М, Чеховська Л. Кадрові потреби сфери оздоровчого фітнесу в Україні. Науковий часопис НПУ ім. Драгоманова. 2019;2(108):4652.

4. Дутчак МВ, Катерина УМ, Чеховська ЛЯ Професійний стандарт - запорука якісного функціонування фітнес-індустрії України. Молодь та олімпійський рух: тези доп. ХІІ Міжнар. конф. молодих вчених. Київ; 2019. с. 301-303.

5. Єдиний фрітнес-стандарт України [Інтернет] [цитовано 2020 Січ 20]. Доступно: https:// uastandart.fitness/

6. Кабінет Міністрів України. Про затвердження плану заходів із впровадження Національної рамки кваліфікацій на 2016-2020 роки [Internet]. Розпорядження № 1077-р. 2016 Гру день 14. Доступно: https://zakon.rada.gov.ua/ laws/show/1077-2016- \%D1 \%80/card2\#Card

7. Класифікатор професій ДК 003:2010: наказ Міністерства економічного розвитку торгівлі від 28.07.2010 р. № 327

8. Куліш НМ. Кадрове забезпечення фізичної культури і спорту в Україні з погляду соціальної сфери. Молодий вчений. 2016; (28):91-94.

9. Прима А. Формирование готовности бу дущих фитнес-тренеров к профессиональной деятельности в фитнес-индустрии: проблемы и перспективы. Наукові записки Терноп. нац. пед ун-ту. 2017;(3):52-60.

10. Усенко Д. Наукові підходи до стандартизації просесійної діяльності фрітнес-консультанта. Теорія і методика фіз. виховання спорту. 2019; (2):73-79.

11. Усенко Д. Діяльність фітнес-консультанта в Україні: затребуваність та особливості професії. Теорія і методика фріз. виховання спорту. 2019;(3):74-80

12. Чеховська ЛЯ. Теоретико-методичн основи організаційного та кадрового забезпе чення системи оздоровчого фітнесу в Україні [дисертація]. Львів; 2020.561 с.

13. Aghyppo 0 . Analysis of the current state of implementation of fitness clubs personne policy. Slobozhanskyi herald of science and sport. 2018;6(68):4-7.
14. Dutchak M, Chekhovska L. Staffing as a topical issue of the modern fitness industry. Slobozhanskyi herald of science and sport. 2018;6 (68):26-31. doi: 10.5281/zenodo.2553338

15. EuropeActive Standards [Electronic resource]. - Access mode: http://www.ehfa-standards. eu/es-standards (date of application: 03.04.2018)

16. International Consortium for Health \& Wellness Coaching (NBHWC) [Internet]. Available from: http://www.ehfa-standards.eu/es-standards

17. National Consortium for Credentialing of Health \& Wellness Coaches A Call To Action. Http:// ncchwc.org/index.cfm?Page=action Accessed May 31, 2013

18. National Occupational Standards [Internet]. Available from: https://www.skillsactive.com/ standards-quals/national-occupational-standards

19. Usenko D, Dutchack M, Potop V, Katerina U, Kurdybakha O. Scientific Substantiation of the Fitness Consultant's Professional Standard in Ukraine. Journal of Physical Education and Sport (JPES). 2019;(19): 2334 - 2338.

\section{LITERATURE}

1. Andrieieva 0, Dutchak M, Blahii 0. Theoretical bases of health related and recreational motor activity of different population groups. Theory and methods of physical education and sports. 2020;2:59-66 doi: 10.32652/tmfvs.2020.2

2. Vasylenko MM. Theoretical and methodological principles of professional training of future fitness trainers in higher education institutions [avtoreferat]. Kyiv; 2018; 44 p.

3. Dutchak M, Chekhovska L. Staffing needs of health fitness field in Ukraine. Scientific journal of National Dragomanov Pedagogical University. 2019;2(108):46-52.

4. Dutchak MV, Kateryna UM, Chekhovska LYa. Professional standard is a guarantee of quality functioning of the fitness industry in Ukraine. Youth and the Olympic Movement: Proc. of the XII Internat. conf. of young scientists. Kyiv; 2019. p. 301-303.

5. Unified Fitness Standard of Ukraine [Internet]. [cited on January 20, 2020]. Retrieved from: https://uastandart.fitness/

6. Cabinet of Ministers of Ukraine. On approval of the action plan for the implementation of the National Qualifications Framework for 2016-2020 [Internet]. Order No. 1077-r. 2016, December 14. Retrieved from: https://zakon.rada.gov.ua/laws/ show/1077-2016- \%D1 \%80/card2\#Card

7. Classifier of Occupations of Ukraine DK 003:2010: Order of the Ministry of Economic Development and Trade on July 28, 2010 No. 327

8. Kulish NM. Human resourcing of physical culture and sport in Ukraine in terms of social sphere. Young scientist. 2016;1(28):91-94.

9. Pryma A. Formation of readiness of the future fitness trainers to professional activities in the fitness industry: problems and prospects. Naukovi zapysky Ternop. nats. ped. un-tu. 2017;(3):52-60.

10. Usenko D. Scientific approaches to standardization of professional activity of a fitness consultant. Theory and methods of physical education and sports. 2019; (2):73-79.

11. Usenko D. Activities of a fitness consultant in Ukraine: demand for and features of the profession. Theory and methods of physical education and sports. 2019;(3):74-80. 
12. Chekhovska LYa. Theoretical and methodological principles of organizational and staffing support for the system of health-enhancing fitness in Ukraine [dissertation]. Lviv; 2020. 561 p.

13. Aghyppo 0. Analysis of the current state of implementation of fitness clubs personne policy. Slobozhanskyi herald of science and sport 2018;6(68):4-7.

14. Dutchak M, Chekhovska L. Staffing as a topical issue of the modern fitness industry. Slobozhanskyi herald of science and sport 2018;6(68):26-31. doi: 10.5281/zenodo.2553338

15. EuropeActive Standards [Electronic resource]. - Access mode: http://www.ehfastandards.eu/es-standards (date of application: 03.04.2018).

16. International Consortium for Health \& Wellness Coaching (NBHWC) [Internet] Available from: http://www.ehfa-standards.eu/ es-standards
17. National Consortium for Credentialing of Health \& Wellness Coaches A Call To Action. Http://ncchwc.org/ index.cfm?Page=action Accessed May 31, 2013

18. National Occupational Standards [Internet]. Available from: https://www.skillsactive.com/ standards-quals/national-occupational-standards

\section{ІНФОРМАЦІЯ ПРО АВТОРІВ}

Дутчак Мирослав Васильович https://orcid.org/0000-0001-6823-272X, mvd21@ukr.net Національний університет фрізичного виховання і спорту України 03150, Київ, вул. Фізкультури, 1

\section{INFORMATION ABOUT THE AUTHORS}

Dutchak Myroslav https://orcid.org/0000-0001-6823-272X, mvd21@ukr.net National University of Ukraine on Physical Education and Sport 03150, Kyiv, Fizkul'tury str., 1 